Journal of American Studies, 56 (2022), I, I 42-166

(C) The Author(s), 202 r. Published by Cambridge University Press in association with the British Association for American Studies. This is an Open Access article, distributed under the terms of the Creative Commons Attribution licence (http://creativecommons.org/licenses/by/4.o/), which permits unrestricted re-use, distribution, and reproduction in any medium, provided the original work is properly cited.

doi:10.1017/S0021875821000529 First published online 12 May 2021

\title{
Rethinking the Scopes Trial: Cultural Conflict, Media Spectacle, and Circus Politics
}

\author{
TOM ARNOLD-FORSTER
}

The Scopes trial has long been interpreted through claims about science and religion and about individual rights and liberties. This article recovers a different debate about the trial's political history that emerged in the later I 920 s and resonated down the twentieth century. Here the trial figured as a fraught national circus, which raised difficult questions about the relationship between media spectacle and cultural conflict in the United States. The trial's circus dynamics intensified the conflicts it staged without ever actually resolving them; this trap was then perceived and negotiated in different ways by contemporary liberals, conservatives, socialists, and far-right activists.

Before John Scopes was even convicted of teaching evolution in Tennessee in July i 925 , arguments raged over his trial's broader historical significance. The New York Times claimed that the Scopes trial generated "the greatest debate on science and religion in recent years," and later historians often explored its importance for the development of evolution, creationism, and fundamentalism. ${ }^{\mathrm{I}}$ But scholars have also seen the trial as raising issues that went "beyond

Gonville and Caius College, University of Cambridge. Email: tpa24@cam.ac.uk.

I "Bryan Defends Tennessee and Its Law," New York Times, I7 July 1925, I. Historical accounts of the trial's significance as a debate about science and religion include Ernest R. Sandeen, The Roots of Fundamentalism: British and American Millenarianism, I80o1930 (Chicago: The University of Chicago Press, 1970); George M. Marsden, Fundamentalism and American Culture: The Shaping of Twentieth-Century Evangelicalism (New York: Oxford University Press, 1980); Ferenc Morton Szasz, The Divided Mind of Protestant America, I880-1930 (Tuscaloosa: University of Alabama Press, 1982); Paul M. Waggoner, "The Historiography of the Scopes Trial: A Critical Re-evaluation," Trinity Journal, 5, 2 (Fall 1984), 155-74; Martin E. Marty, Modern American Religion, Volume II, The Noise of Conflict, I9I9-I94I (Chicago: The University of Chicago Press, 1990); Ronald L. Numbers, The Creationists: The Evolution of Scientific Creationism (Berkeley: University of California Press, 1993); Numbers, Darwinism Comes to America (Cambridge, MA: Harvard University Press, 1998); George E. Webb, The Evolution Controversy in America (Lexington: University Press of Kentucky, 1994); 
science and religion."2 William Jennings Bryan insisted that Scopes threatened the democratic control of public education, while Clarence Darrow countered that Scopes had the right to teach the truth no matter what the public wanted. And many others saw all sorts of issues at stake in the trial, ranging from questions about racial justice and gender norms to debates about regional identity and fundamentalist movement strategy. ${ }^{3}$ The trial's historiography has thus

Joel A. Carpenter, Revive Us Again: The Reawakening of American Fundamentalism (New York: Oxford University Press, 1997); Jane Maienschein, "Diversity in American Biology, 1900-1940," History and Philosophy of the Life Sciences, 21, I (1999), 35-52; Paul J. Pauly, Biologists and the Promise of American Life: From Meriwether Lewis to Alfred Kinsey (Princeton, NJ: Princeton University Press, 2000); Mark Edwards, "Rethinking the Failure of Fundamentalist Political Antievolutionism after 1925," Fides et Historia, 32, 2 (Summer/Fall 2000), 89-106; Peter J. Bowler, Monkey Trials and Gorilla Sermons: Evolution and Christianity from Darwin to Intelligent Design (Cambridge, MA: Harvard University Press, 2007); Kevin M. Schultz, "World War I and After: Godlessness and the Scopes Trial," in Charles Mathewes and Christopher McKnight Nichols, eds., Prophesies of Godlessness: Predictions of America's Imminent Secularization, from the Puritans to the Present Day (New York: Oxford University Press, 2008), 137-53; Alexander Pavuk, "Evolution and Voices of Progressive Catholicism in the Age of the Scopes Trial," Religion and American Culture, 26, I (Winter 2016), I0I37; Pavuk, "The American Association for the Advancement of Science Committee on Evolution and the Scopes Trial: Race, Eugenics, and Public Science in the U.S.A.," Historical Research, 95, 25 I (Feb. 2018), 137-59.

2 Adam R. Shapiro, "The Scopes Trial beyond Science and Religion," in Thomas Dixon, Geoffrey Cantor, and Stephen Pumfrey, eds., Science and Religion: New Historical Perspectives (Cambridge: Cambridge University Press, 2010), 198-220; Shapiro, Trying Biology: The Scopes Trial, Textbooks, and the Antievolution Movement in American Schools (Chicago: The University of Chicago Press, 2013), I. See also Matthew Avery Sutton, American Apocalypse: A History of Modern Evangelicalism (Cambridge, MA: Harvard University Press, 2014), viii: "historians [of American religion] have exaggerated the significance of the Scopes trial." For further evidence of scholarly ambivalence about science-religion frameworks see James Moore, "Religion and Science," in Peter J. Bowler and John V. Pickstone, eds., The Cambridge History of Science, Volume VI, The Modern Biological and Earth Sciences (Cambridge: Cambridge University Press, 2009), 54I-62, esp. 544; Edward J. Larson, "Myth 20: That the Scopes Trial Ended in Defeat for Anti-evolutionism," in Ronald L. Numbers, ed., Galileo Goes to Jail and Other Myths about Science and Religion (Cambridge, MA: Harvard University Press, 2009), 176-86; John Hedley Brooke, "Modern Christianity," in John Hedley Brooke and Ronald L. Numbers, eds., Science and Religion around the World (New York: Oxford University Press, 201 I), 92I I9, esp. Iıо; Thomas H. Aechtner, "Social Scientists," in Jeff Hardin, Ronald L. Numbers, and Ronald A. Binzley, eds., The Warfare between Science and Religion: The Idea That Wouldn't Die (Baltimore: Johns Hopkins University Press, 2018), 302-23, esp. 3 I 3 .

3 Jeffrey P. Moran, "Reading Race into the Scopes Trial: African American Elites, Science, and Fundamentalism," Journal of American History, 90, 3 (Dec. 2003), 89 I-9 I I; Moran, "The Scopes Trial and Southern Fundamentalism in Black and White: Race, Region, and Religion," Journal of Southern History, 70, I (Feb. 2004), 95-I20; Moran, American Genesis: The Antievolution Controversies from Scopes to Creation Science (New York: Oxford University Press, 2012), esp. 28-46; Andrew Nolan, "Making Modern Men: The Scopes Trial, Masculinity and Progress in the 1920 United States," Gender and History, 
sought to reconcile these wider arguments with science-religion frameworks. The current standard account concludes that "the issues raised by the Scopes trial and legend endure precisely because they embody the characteristically American struggle between individual liberty and majoritarian democracy, and cast it in the timeless debate over science and religion."4

This article reassesses the trial's significance by showing how key parts of its political history not only went beyond science and religion but also departed from the issue of individual liberty. For among the many arguments generated by the Scopes trial was a crucial debate about the politics of staging a national "circus." Contemporaries regularly used this metaphor to interpret the trial as a media spectacle that dramatized a series of interlocking cultural conflicts between science and religion, urban and rural, elite and popular, North and South. 5 However, later historians often depoliticized these interpretations by seeing the trial's spectacular circus dynamics as little more than fun but frothy "ballyhoo." 6 Meanwhile recent scholarship in media history and communications studies has shown how sensational coverage helped define the trial's reception. ${ }^{7}$ By taking the circus seriously and seeing its publicity as

I9, I (April 2007), I 22-42; Michael Lienesch, In the Beginning: Fundamentalism, the Scopes Trial, and the Making of the Antievolution Movement (Chapel Hill: University of North Carolina Press, 2007); Angie Maxwell, The Indicted South: Public Criticism, Southern Inferiority, and the Politics of Whiteness (Chapel Hill: University of North Carolina Press, 2014); Shantá R. Robinson, "A Crusader and an Advocate: The Black Press, the Scopes Trial, and Educational Progress," Journal of Negro Education, 87, I (Winter 20I8), 5-2 I.

${ }^{4}$ Edward J. Larson, Summer for the Gods: The Scopes Trial and America's Continuing Debate over Science and Religion (New York: Basic Books, 1997), 265.

5 E.g. H. L. Mencken, "The Tennessee Circus," Baltimore Evening Sun, I 5 June 1925, in Mencken, A Religious Orgy in Tennessee: A Reporter's Account of the Scopes Monkey Trial (Hoboken, NJ: Melville House, 2006), 3-9. On spectacles in modern America see Andrew M. Fearnley, "New Studies of Spectacle and Spectatorship in the United States: An Introduction," European Journal of American Studies, 14, 4 (2019), I-7 (and the other articles in this special issue).

${ }^{6}$ This tendency goes back to Frederick Lewis Allen, Only Yesterday: An Informal History of the Nineteen-Twenties (New York: Harper, 193 I), chapter 8, "The Ballyhoo Years." See also Laurence Greene, The Era of Wonderful Nonsense: A Casebook of the Twenties (New York: Bobbs-Merrill, I 939), 134-53; Jerry R. Tompkins, ed., D-Days at Dayton: Reflections on the Scopes Trial (Baton Rouge: Louisiana State University Press, 1965); Stephen Jay Gould, Hen's Teeth and Horses' Toes: Further Reflections in Natural History (New York: Norton, 1983), 263-79; Kenneth M. Weiss, "The Scopes Trial," Evolutionary Anthropology, 16, 4 (July-Aug. 2007), I26-31; Lawrence M. Friedman, The Big Trial: Law as Public Spectacle (Lawrence: University Press of Kansas, 2015).

7 Mary Beth Swetnam Mathews, Rethinking Zion: How the Print Media Placed Fundamentalism in the South (Knoxville: University of Tennessee Press, 2006), 83-90; Constance Areson Clark, God-or Gorilla: Images of Evolution in the Jazz Age (Baltimore: Johns Hopkins University Press, 2008); Edward Caudill, Intelligently Designed: How Creationists Built the Campaign against Evolution (Urbana: University of 
significant politically, this article argues that the trial's politics were both more fraught and more consequential than has generally been appreciated. Many prominent commentators in the mid-and late i920s saw the Scopes trial not as a contest between science and religion, nor as a struggle over individual rights and liberties, but rather as a broader debate about the political relationship between cultural conflict and media spectacle in the United States.

Historians of education have sometimes seen this relationship, as well as the trial itself, through the lens of later "culture wars." From this perspective, the Scopes trial anticipated the stark cultural battle lines that have shaped American politics since the 1980 s, especially through debates over curriculum design. ${ }^{8}$ But what the culture-war heuristic misses and what the circus metaphor captures, is how the trial's cultural conflicts not only went beyond education policy but also became essentially unwinnable, crucially symbiotic, and primarily spectacular. Rather than dividing the United States into two warring cultures over who controlled the public schools, the Scopes trial combined various cultural conflicts into a single media spectacle. And the resulting circus politics encouraged circular arguments with conservative outcomes. Liberals approached the trial by advocating modernization and consensus, but the right responded by making anti-liberal arguments for traditional cultural values, which the far right tried to radicalize while the left found itself marginalized. In this sense the Scopes trial was not simply a culture war about education, but nor was it a just a bit of ballyhoo that can be separated from the broader political history of 1920 s America. ${ }^{9}$ As a significant part of this history, the Scopes trial helps explain why the United States has sometimes been engulfed by spectacular cultural conflicts and seemed incapable of structural transformations in its economic and racial regimes.

So the trial became a circus, and the circus became a trap: an all-consuming and self-sustaining spectacle that served to escalate cultural conflicts and entrench existing resentments through ever more sensational media coverage.

Illinois Press, 2013); Perry Parks, "Summer for the Scientists? The Scopes Trial and the Pedagogy of Journalism," Journalism \& Mass Communications Quarterly, 92, 2 (June 2015), 444-67.

8 Jonathan Zimmerman, Whose America? Culture Wars in the Public Schools (Cambridge, MA: Harvard University Press, 2002); Adam Laats, Fundamentalism and Education in the Scopes Era: God, Darwin, and the Roots of America's Culture Wars (New York: Palgrave Macmillan, 2010); Laats, The Other School Reformers: Conservative Activism in American Education (Cambridge, MA: Harvard University Press, 2015).

9 That is, from the history explored in such books as Moshik Temkin, The Sacco-Vanzetti Affair: America on Trial (New Haven, CT: Yale University Press, 2009); Lisa McGirr, The War on Alcohol: Probibition and the Rise of the American State (New York: Norton, 2016); Linda Gordon, The Second Coming of the KKK: The Ku Klux Klan of the rozos and the American Political Tradition (New York: Norton, 2017). 
To explain these processes, this article will proceed in three parts. The first will explore the trial itself and suggest that its politics were more defined by circus dynamics than by debates about science and religion or about Scopes's rights and liberties. The second part will examine how contemporary liberals, conservatives, socialists, and far-right activists continued arguing about the trial's legacies in the later I920s. The third part will survey the broader resonance of these arguments down the twentieth century and consider their relationship to the trial's changing meanings during the New Deal and Cold War.

No one knew in early July 1925 that William Jennings Bryan would be dead by the end of the month. Most saw him as the charismatic Democrat that he had been since I 896, when he won unprecedented support across the South and West as the presidential nominee of the Democratic and People's parties. Though he lost the election, Bryan's career flourished with two more tries at the presidency, a stint as Secretary of State, and several tours of the Chautauqua circuit. ${ }^{10}$ "He was the greatest political evangelist of his day," wrote the political scientist Charles Merriam, stressing that "his strength was peculiarly recruited from the agrarian group, the labor group, and the religious group cutting across economic class lines." " I Bryan campaigned against evolution as a veteran politician with a large constituency and did not confine his campaign to debates about science and religion. Scientists and theologians had long disputed Darwin's theories and argued in particular about their ontological repercussions for various forms of religious belief. ${ }^{12}$ Bryan, however, focussed on their broader political implications. ${ }^{13}$ Above all he argued that

10 Elizabeth Sanders, The Roots of Reform: Farmers, Workers, and the American State (Chicago: The University of Chicago Press, 1999), I 38-47, 154-58; Charles Postel, The Populist Vision (New York: Oxford University Press, 2007), 21-22; Daniel Scroop, "William Jennings Bryan's 1905-1906 World Tour," Historical Journal, 56, 2 (June 2013), 45986; Jeremy C. Young, The Age of Charisma: Leaders, Followers, and Emotions in American Society, 1870-1940 (Cambridge: Cambridge University Press, 2017), 40-42.

${ }^{11}$ Charles E. Merriam, Four American Party Leaders (New York: Macmillan, 1926), 73, 82.

12 James R. Moore, The Post-Darwinian Controversies: A Study of the Protestant Struggle to Come to Terms with Darwin in Great Britain and America, 1870-1900 (Cambridge: Cambridge University Press, 1979); James C. Turner, Without God, Without Creed: The Origins of Unbelief in America (Baltimore: Johns Hopkins University Press, 1985); Jon H. Roberts, Darwinism and the Divine in America: Protestant Intellectuals and Organic Evolution, 1859-1900 (Madison: University of Wisconsin Press, 1988).

13 Thus Bryan argued that evolution undermined equality because it threatened everyone's spiritual integrity and promoted eugenics. He also claimed that evolution damaged citizenship because it eroded religious beliefs without which citizens could not love and therefore respect each other. See William Jennings Bryan, The Prince of Peace (New York: Funk \& Wagnalls, 1916), I8; Bryan, In His Image (New York: Fleming H. Revell, I922), I I0; 
public education was a democratic question and that the people should choose what was taught in their schools. ${ }^{14}$ And though his fame presented fundamentalist leaders with political opportunities, Bryan's actual religious beliefs were far from orthodox fundamentalism. ${ }^{15}$ His antievolution campaign, then, was a successful political movement supported by rural and religious citizens regionally concentrated in the South and West.

The combination of these various cultural vectors seemed striking and threatening to secular urban liberals in the North and East, who generally saw themselves as stewards of modernization. "Bryan is what America was," Walter Lippmann had written; "his critics are generally defenders of what America has become." ${ }^{16}$ But as Bryan's campaign became more powerful, many liberals grew anxious. John Dewey criticized Bryan as an antimodern crusader, but also wrote that "the forces which are embodied in the present crusade would not be so dangerous were they not bound up with so much that is necessary and good." To meet these dangers while maintaining the good, Dewey urged greater intellectual and political humility and warned against departing from popular norms "associated with aspiration for a decent neighborly life." ${ }^{17}$ Still, some cared little about sounding condescending. The Princeton biologist and avid eugenicist Edwin Grant Conklin told the New York Times that Bryan's campaign "would be amusing if it were not so pathetic." ${ }^{8} 8$ But Bryan knew how to make such claims work in his

Michael Kazin, Godly Hero: The Life of William Jennings Bryan (New York: Alfred A. Knopf, 2006), 263; Lienesch, In the Beginning, 87-88; Kristy Maddux, "Fundamentalist Fool or Populist Paragon? William Jennings Bryan and the Campaign against Evolutionary Theory," Rhetoric and Public Affairs, 16, 3 (Fall 2013), 489-520, 503-5.

${ }^{14}$ William Jennings Bryan, Seven Questions in Dispute (New York: Fleming H. Revell, 1924), I 55. On Bryan and democracy see Lawrence W. Levine, Defender of the Faith: William Jennings Bryan: The Last Decade, I9I5-1925 (New York: Oxford University Press, 1965), 2 $18-27$; Kazin, xviii-xxi, 274-77.

is Bryan's Christianity was ecumenically Presbyterian, postmillennialist, and basically optimistic about the religious destiny of believers. But many fundamentalists were Baptists or Methodists, and most were premillennialists, which made them more anxious about the issue of individual salvation. See Szasz, The Divided Mind, i I5; Sutton, American Apocalypse, 166-68.

${ }^{16}$ Walter Lippmann, Drift and Mastery (Madison: University of Wisconsin Press, 1985 ; first published I9I4), 8 I.

17 John Dewey, "The American Intellectual Frontier," New Republic, ro May 1922, 303-5. See also Robert B. Westbrook, John Dewey and American Democracy (Ithaca, NY: Cornell University Press, I991), 314-16, esp. 3 16 n. 39.

${ }^{18}$ Edwin Grant Conklin, "Bryan and Evolution," New York Times, 5 March 1922, Sec. 7, I 4; Alexander Pavuk, "Biologist Edwin Grant Conklin and the Idea of the Religious Direction of Human Evolution in the Early 1920s," Annals of Science, 74, I (2017), 64-82. See also Paul K. Conkin, When All the Gods Trembled: Darwinism, Scopes, and American Intellectuals (Lanham, MD: Rowman \& Littlefield, 1998). 
favor and he responded that figures like Conklin "misrepresent their opponents, look with contempt upon those who do not exhaust the alphabet in setting forth their degrees, and evade the issue which they pretend to discuss." ${ }^{19}$ As a sneering Princeton professor who wanted public attention, Conklin provided the perfect foil for Bryan.

Elite or popular, urban or rural, science or religion, North or South; these interlocking conflicts had a real political resonance in 1920 S Tennessee. Most citizens lived in rural areas or small towns; in general they valued the Bible, had voted for Bryan, disliked taxation, and enjoyed a good courthouse performance. $^{20}$ Meanwhile local urban liberals in Nashville and Chattanooga opposed Bryan and emphasized the importance of education. Tennessee's politics involved much Protestant conservatism and some more progressive elements, alongside wider commitments to racial segregation and New South liberalism. ${ }^{21}$ So when John Washington Butler, a legislator from the rural Upper Cumberland, wanted to ban Tennessee's public schools from teaching evolution, his bill became state law without much fuss. ${ }^{22}$ But the law became the spark for national debate through conscious media strategies. From its New York headquarters, the American Civil Liberties Union (ACLU) announced that it would challenge the law in a press release reaching the small town of Dayton, where local boosters arranged Scopes's arrest and told the press. ${ }^{23}$ As national coverage mounted, some Tennesseans warned of impending public embarrassment. "Is it not time for progressive minded people to put themselves on record," Donald Davidson asked in the Nashville Tennessean, "so that whether the victory be lost or won, the outside world may know that Tennessee is not a total fog of Bryanism?" 24 Still, most such people kept quiet, and Davidson's own mind grew much less progressive after the trial ended.

${ }^{19}$ Quoted in Levine, $287-88$.

20 See Jeanette Keith, Country People in the New South: Tennessee's Upper Cumberland (Chapel Hill: University of North Carolina Press, 1995), 54-57, 63-64, I7 I-74, 210.

${ }^{21}$ C. Vann Woodward, Origins of the New South, 1877-1913 (Baton Rouge: Louisiana State University Press, I971; first published 1951), 46I; Cynthia Griggs Fleming, "The Plight of Black Educators in Postwar Tennessee, I 865-1920," Journal of Negro History, 64, 4 (Fall 1979), 355-64; David D. Lee, Tennessee in Turmoil: Politics in the Volunteer State, 1920-1932 (Memphis, TN: Memphis State University Press, 1979), 52-53; Charles A. Israel, Before Scopes: Evangelicalism, Education and Evolution in Tennessee, 1870-1925 (Athens: University of Georgia Press, 2004), i I 6-26; Natalie J. Ring, The Problem South: Region, Empire, and the New Liberal State, 1880-1930 (Athens: University of Georgia Press, 2012), 162-72.

23 The caper is recounted in Larson, Summer for the Gods, $8 \mathrm{I}-92$.

${ }^{24}$ Quoted in Paul V. Murphy, The Rebuke of History: The Southern Agrarians and American Conservative Thought (Chapel Hill: University of North Carolina Press, 200I), I47. Cf. Joseph Wood Krutch, “Tennessee: Where Cowards Rule," Nation, I 5 July I925, 88-89. 
Bryan sensed opportunity. When he went to Dayton as a celebrity prosecutor, Merriam worried that "Mr. Bryan is likely to sweep the board, for he has now found an issue which involves no special economic considerations and where his well-known eloquence and piety give him enormous strength."2s The ACLU, moreover, struggled to develop a clear legal strategy. The organization's director, Roger Baldwin, argued that the trial turned on the issue of academic freedom, which he wanted to ground in First Amendment speech rights. ${ }^{26}$ Others within the ACLU thought that the Butler Act amounted to the establishment of religion by the state of Tennessee, which involved different First Amendment rights. ${ }^{27}$ Both these arguments strained, because "free speech in the classroom" then lacked legal precedent and the "religious-establishment" claim meant seeing schools as churches. The broader unconstitutionality of the Butler Act was also doubtful, because First Amendment rights were not then generally enforceable at the federal level under the Fourteenth Amendment. ${ }^{28}$ When Darrow joined Scopes's defense team, some ACLU allies distanced themselves from the trial. Felix Frankfurter tried to get Darrow off the case and argued publicly that beating Bryan meant winning over public opinion rather than relying on judicial decisions. ${ }^{29}$ Samuel Untermeyer refused to help the ACLU with the case, but he also told Bryan that the prevailing "grand-stand play" would make it difficult "to keep the trial within the legal limits." $3 \circ$

Indeed, the trial was a spectacle from the start. About two hundred journalists went to Dayton and over two thousand newspapers published their articles on "the queerest story of the generation," as Editor \& Publisher put it, "weird as a nightmare, side-splittingly funny, darkly tragic, a huge joke, a sinister threat ... all about everything and all about nothing." ${ }_{31}$ Whipping things up most

${ }^{25}$ Charles E. Merriam to John Merriam, Io July 1925, quoted in Barry D. Karl, Charles E. Merriam and the Study of Politics (Chicago: The University of Chicago Press, 1974), I $22-23$.

${ }^{26}$ This argument retreated from Baldwin's earlier identification of free speech with labor issues: see Laura Weinrib, The Taming of Free Speech: America's Civil Liberties Compromise (Cambridge, MA: Harvard University Press, 2016), 146-48. See also Judy Kutulas, The American Civil Liberties Union and the Making of Modern Liberalism, 1930-1960 (Chapel Hill: University of North Carolina Press, 2006).

${ }^{27}$ David Walker, In Defense of American Liberties: A History of the ACLU, 2nd edn (Carbondale: Southern Illinois University Press, 1999; first published 1990), 73.

${ }^{28}$ Gary Gerstle, Liberty and Coercion: The Paradox of American Government from the Founding to the Present (Princeton, NJ: Princeton University Press, 201 5), 82-85.

${ }^{29}$ Felix Frankfurter, "Supreme Court Upholds Tolerance," New Orleans Times-Picayune, 17 July 1925, I0; Larson, Summer for the Gods, I0 I-2.

30 Levine, Defender of the Faith, 337; Walker, 77-79.

${ }^{31}$ Gregory C. Lisby and Linda L. Harris, "Georgia Reporters at the Scopes Trial: A Comparison of Newspaper Coverage," Georgia Historical Quarterly, 75, 4 (Winter 1991), $784-803,785$. 
was H. L. Mencken, who had made his name by mocking democracy, Christianity, and the South, and who found the whole show "five times better than I expected." ${ }^{2}$ Mencken's dispatches framed the trial's significance through a series of spectacular cultural conflicts. Some of these involved oppositions between science and religion, and one of his pieces portrayed a local "religious orgy." 33 But many other pieces made claims about regional barbarity, rural backwardness, and Bryan's demagoguery. "The rabble is in the saddle," Mencken wrote with rapt revulsion, "and down here it makes its first campaign under a general beside whom Wat Tyler seems like a wart beside the Matterhorn." 34 Beyond the content of his journalism, Mencken's very presence seemed to raise the resentment stakes. When he left Dayton early to deal with editorial duties in Baltimore, a rumor that angry locals had chased him out of town became a national story. "Mencken's Epithets Raise Dayton's Ire," splashed the New York Times. "Citizens Resent Being Called 'Babbitts,' 'Morons,' 'Peasants,' 'Hill-Billies,' and 'Yokels'; Talk of Beating Him Up." ${ }^{35}$ This was not true, but nor did it need to be. What mattered was the semi-ironic headline and its grievance-mongering frisson.

The trial's abundant ballyhoo had the political function of amplifying and escalating its cultural conflicts while foreclosing the possibility of either resolving them or moving on to other issues. The Manchester Guardian reported that Daytonians most disliked "the spectacle of many outsiders coming a distance to tell them what to do." ${ }^{36}$ But as an outsider itself and especially as a British publication, the Guardian could not hope to observe the spectacle without magnifying its conflicts. Scopes's conviction was a foregone conclusion, yet many contemporaries saw the trial's real significance in its everincreasing publicity. Julia Collier Harris, a Georgia journalist and New South liberal, argued that "fundamentalism of every kind is spreading its flamboyant banners in Dayton." 37 From Bryan's perspective, however, the

${ }^{32}$ H. L. Mencken to Sara Haardt, 8 July 1925 , in Marion Elizabeth Rodgers, ed., Mencken and Sara: A Life in Letters (New York: McGraw-Hill, 1987), 217.

${ }^{33}$ H. L. Mencken, "Mencken Likens Trial to a Religious Orgy, with Defendant a Beelzebub," Baltimore Evening Sun, I I July I 925, in Mencken, A Religious Orgy in Tennessee, 44. For an incisive anthropological account of these conflicts, and especially on Mencken's role in fueling them, see Susan Harding, "Representing Fundamentalism: The Problem of the Repugnant Cultural Other," Social Research, 58, 2 (Summer I99I), 373-93, 380-85.

${ }^{34}$ H. L. Mencken, "Darrow's Eloquent Appeal Wasted on Ears That Heed Only Bryan, Says Mencken," Baltimore Evening Sun, I 4 July 1 925, in Mencken, A Religious Orgy in Tennessee, 66.

35 "Mencken's Epithets Raise Dayton's Ire," New York Times, I7 July 1925, 3; Marion Elizabeth Rodgers, Mencken: The American Iconoclast (New York: Oxford University Press, 2005), 289-90.

36 "Anti-Darwin Law Challenged," Manchester Guardian, I 4 July I 925 , I I.

37 Lisby and Harris, "Georgia Reporters at the Scopes Trial," 792. 
flamboyancy of the banners was critical. In fact, he focussed more directly on the role of the press as the trial proceeded. "Irreligious editors," Bryan argued, "have scoffed at the idea of the schools being controlled by those who support them." ${ }^{8}$ Ordinary citizens, he suggested, would rightly resent the smirks of the liberal media. The trial's circus dynamics thus drew in journalists themselves as both participants and observers, both publicists and reporters.

Some journalists tried to cover the trial in ways that confronted its conflicts and reached for consensus. For example, Marcet Haldeman-Julius wrote a careful account for the Haldeman-Julius Monthly, an independent socialist paper that she edited with her husband Emanuel. 39 Seeking to cool "the super-heated, jazzy atmosphere" that seemed so dominant, she portrayed John Washington Butler as a good man, "full of innate courtesy and kindness," much like her own friends and neighbors in Girard, Kansas. He told Haldeman-Julius that "the way you've been raised" explained your political views; she told her readers that despite Bryan's campaign against evolution, "Mr. Butler and many of his fellow Tennesseans have been proudly interested as well as informed and set quietly thinking by the campaign of education carried on at Dayton by Darrow."40 In Haldeman-Julius's account, the trial served to educate Daytonians about evolution rather than fuel opposition to outsiders. But even if some local citizens became more interested in evolution itself because of the trial, the prospects for consensus beyond it were bleak. Joseph Wood Krutch had grown up in Tennessee and now worked in New York for The Nation; he saw the trial as "a symptom of the vast gulf which lies between the two halves of our population." And yet he offered no real answer to "the question of how this gulf may be bridged." 4 I

Moreover, the most popular and influential coverage of the Scopes trial was directly invested in keeping the circus going. The Haldeman-Julius Monthly and the weekly Nation had tiny circulations compared with major commercial dailies like the Chicago Tribune, but these were the papers that saw the trial as pure entertainment. The Tribune sent its star reporter Philip Kinsley to Dayton; he wrote pieces that described Darrow as a dashing "Chicago prophet" beneath headlines like "DARROW RIPS INTO BIGOTRY."42 Nor could Kinsley resist deriding Bryan's career as a Florida real-estate

38 "Bryan Defines Dayton Issues in Address to the People," Chicago Tribune, 8 July i 925, 2.

39 Jason Barrett-Fox, "Feminism, Socialism, and Pragmatism in the Life of Marcet HaldemanJulius, I 887-194I," MA thesis, University of Kansas, 2008; R. Alton Lee, Publisher for the Masses, Emanuel Haldeman-Julius (Lincoln: University of Nebraska Press, 20 17).

$4^{\circ}$ Marcet Haldeman-Julius, Clarence Darrow's Two Great Trials (Girard, KS: HaldemanJulius Company, 1927), 3, 17-18, 20.

${ }^{41}$ Joseph Wood Krutch, "Tennessee's Dilemma," The Nation, 22 July i 925 , i 10.

42 Philip Kinsley, "Darrow Rips into Bigotry," Chicago Tribune, I 4 July 1925 , I. 
dealer. ${ }^{43}$ But the Tribune also had an economic interest in sustaining the trial's spectacle. As a commercial product in a competitive media market, the paper relied on events like the Scopes trial to outsell its rivals. By publishing sensational pieces by journalists like Kinsley and syndicating celebrities like Mencken, and by integrating these editorial choices into broader corporate strategies, the Chicago Tribune achieved a daily circulation of 650,000 in 1925. ${ }^{44}$ It also used new technologies to promote its brand. The Tribune's radio station WGN broadcast the Scopes trial live across the nation - the first time this happened with any American court proceeding-and its very name announced that the Tribune was the "World's Greatest Newspaper."45

The circus politics of the Scopes trial thus turned assorted cultural divisions into a single media spectacle that intensified the conflicts it staged. And these dynamics pushed usually sober journalists towards increasingly polarized arguments. George Fort Milton, the editor of the Chattanooga News and another New South liberal, had argued against banning evolution in Tennessee's public schools but now he sought to defend southern ways from northern attacks. Observing that fundamentalists lived everywhere in America and that the trial could have happened in "Kansas or Missouri, in Washington, or the State of Maine," Milton insisted that Tennessee should not be "crucified on the cross of public opinion as a bog of bigotry." ${ }^{6} 6$ Walter Lippmann, now directing the editorial page of the New York World, began to abandon his earlier policy of publishing letters from liberal Tennesseans lamenting the whole "publicity stunt." 47 As Lippmann ran piece after piece on the "sectarian fury" beneath the "circus atmosphere," he eventually accused Bryan of committing "spiritual treason against the people of the United States." ${ }^{48}$ But

43 Philip Kinsley, "Scopes Case a 'Duel to the Death': W.J.B.," Chicago Tribune, 8 July I 925 , I. On Bryan and Florida see Levine, Defender of the Faith, 237-40.

${ }^{44}$ Julia Guarneri, Newsprint Metropolis: City Papers and the Making of Modern Americans (Chicago: The University of Chicago Press, 2017), 147-93; Michael Stamm, Dead Tree Media: Manufacturing the Newspaper in Twentieth-Century North America (Baltimore: Johns Hopkins University Press, 2018), 107-1 8 .

45 Michael Stamm, Sound Business: Newspapers, Radio, and the Politics of New Media (Philadelphia: University of Pennsylvania Press, 201 I ), 37-39. On the varieties of religious radio, some of which responded to Scopes, see Tona J. Hangen, Redeeming the Dial: Radio, Religion, and Popular Culture in America (Chapel Hill: University of North Carolina Press, 2002).

${ }^{46}$ George Arnold Miller, "George Fort Milton: The Fight for TVA and the Loss of the Chattanooga News," PhD thesis, Middle State Tennessee University, 1983, 27-29.

47 "A Son of Tennessee," letter to the editor, New York World, i7 June 1925, I o. See also Ronald Steel, Walter Lippmann and the American Century (Boston: Little, Brown, 1980), 216-18; Gerald Gunther, Learned Hand: The Man and the Judge, 2nd edn (New York: Oxford University Press, 20 I I; first published 1994), 3 I 8-29.

48 "The Rise of Sectarian Politics," New York World, I o July 1925, I o; "The Spiritual Treason of Bryan," New York World, is July i 925 , io. 
such charges then pushed southern editors to insist that their region could do without the advice and attacks of the New York World. 49

These conflicts and resentments were deepened by the issue of expert testimony. The ACLU had arranged for various experts, mostly (though not only) from northern universities, to give evidence about the scientific truth of evolution and its theological compatibility with Christianity..$^{\circ}$ In response Bryan argued that out-of-town elites ought not to interfere with the decisions of Tennessee's citizens. Speaking in court for the first time, Bryan observed that New Yorkers would naturally oppose efforts to enforce prohibition if Tennesseans sent "experts to testify how good a thing prohibition is to New York and to the nation." And so, he said, "it isn't proper to bring experts in here to defeat the purpose of the people of this state by trying to show that this thing that they denounce and outlaw is a beautiful thing that everybody ought to believe in." ${ }^{\prime}$ Bryan's argument worked in the strict legal sense that most expert testimony was read into the appellate record and not heard by the jury. But it also worked in the broader political sense that anti-Bryan journalists became ever more incensed. The Chicago Tribune saw the exclusion of expertise as evidence that Bryan had gone "mad." ${ }_{52}$ Liberal southern newspapers were drawn further toward Bryan. The New Orleans Times-Picayune had so far avoided taking sides, but now it printed letters from pro-Bryan readers arguing that "you should handle this matter more carefully and give each side the same publicity." ${ }_{53}$

The circus finale came with Darrow's decision to cross-examine Bryan as an expert witness on matters of biblical interpretation. Darrow had tried this before in the pages of the Chicago Tribune, though Bryan refused to debate him there. ${ }^{54}$ However, Bryan now took the stand and submitted to Darrow's questions about the accuracy of the Bible, the age of the Earth, and whether or not the locals were "yokels." ss The Darrow-Bryan encounter was the trial's most spectacular moment, which came to represent the triumph of science over superstition to the likes of Mencken. ${ }^{56}$ Yet the New York World had "no sympathy at all for the manner in which Mr. Darrow heckled Mr.

49 Noted in Edwin Mims, The Advancing South: Stories of Progress and Reaction (London: Heinemann, 1926), 17. More on Mims below.

so Larson, Summer for the Gods, i 86.

51 The World's Most Famous Court Trial: State of Tennessee $v$. John Thomas Scopes (Boston: Da Capo, I97 I; first published 1925), 172.

52 "Bryan," Chicago Tribune, i 8 July i $925,4$.

53 Albert Norling, letter to the editor, New Orleans Times-Picayune, I 9 July 1925 , B6.

54 "Bryan Brushes Darrow Bible Queries Aside," Chicago Tribune, 5 July 1923. Cf. Lienesch, In the Beginning, 83-84.

ss The World's Most Famous Court Trial, 284-304, 288.

${ }^{56}$ H. L. Mencken, "Aftermath," Baltimore Evening Sun, 14 Sep. 1925, in Mencken, $A$ Religious Orgy in Tennessee, I 19-25. 
Bryan." 57 The now pro-Bryan New Orleans Times-Picayune argued that Darrow had "betrayed himself as the bitter, cynical, contemptuous agnostic, intolerant of the faith of simple minds and resentful of the beliefs of a kindly people seeking, perhaps narrowly and unadvisedly yet sincerely and earnestly, to preserve religious concepts in the minds of their children." 58 Marcet Haldeman-Julius observed that most Daytonians "believed their hero was winning," while the Arkansas Gazette judged Bryan "a brave figure to them." 59 Krutch wrote of Bryan that "even as he loses he wins." 60

\section{II}

In the trial's aftermath, the political consequences of its circus dynamics continued to generate fierce debates among liberals, socialists, and conservatives. For it seemed very doubtful that victory belonged to anyone. Scopes had certainly lost; he was convicted of a misdemeanor and fined a hundred dollars by the judge. ${ }^{61}$ And the ACLU lost, because the Butler Act was upheld and no legal precedents were set. The organization hoped that "laws of this kind will hereafter meet the opposition of an aroused public opinion," but the spectacle had been so polarizing that this seemed unlikely. ${ }^{62}$ When Bryan suddenly died five days after the trial ended, few thought him buried. Mencken did his best with a pitiless obituary that called Bryan "a walking malignancy," but most were more respectful. ${ }^{63}$ Even the New York World managed to say some nice things, while also worrying that the drama of Bryan's death would "weight his words at Dayton with the solemnity of a parting message and strengthen their effect on his fellow citizens." ${ }^{64}$ The Last Message of William Jennings Bryan quickly appeared as a pamphlet edited by George Fort Milton, while antievolution activists went on getting bills through the legislatures of Mississippi, Arkansas, and elsewhere. ${ }^{65}$

57 “A Wandering Defense," New York World, 22 July 1925, I0.

58 "Bigots and Bigots," New Orleans Times-Picayune, 22 July 1925, 8.

59 Haldeman-Julius, Clarence Darrow's Two Great Trials, 23; Marvin N. Olasky, "When World Views Collide: Journalists at the Great Monkey Trial," American Journalism, 4, 3 (1987), 1 33-46, I 40.

60 Joseph Wood Krutch, "Darrow vs. Bryan," Nation, 29 July 1925, I 36.

${ }^{61}$ Later overturned by the Tennessee Supreme Court on the technical basis that he should have been fined by the jury. Larson, Summer for the Gods, 2 I $3-2$ I.

${ }_{62}$ Arthur Garfield Hays, "The Strategy of the Scopes Defense," The Nation, 5 Aug. 192 5 , I 57 58. Cf. "The Conduct of the Scopes Trial," New Republic, i9 Aug. 1925, 33 I-33.

${ }^{63}$ H. L. Mencken, "Bryan," Baltimore Evening Sun, 27 July 1925, in Mencken, A Religious Orgy in Tennessee, I04.

${ }^{64}$ "William Jennings Bryan," New York World, 27 July 1925, 10.

${ }^{65}$ George Fort Milton, ed., The Last Message of William Jennings Bryan (New York: Fleming H. Revell, 1925); Numbers, Darwinism Comes to America, 83-85; Lienesch, In the Beginning, $17 \mathrm{I}-73$. 
One of the trial's most incisive postmortems appeared two months later as an editorial in The Crisis by W. E. B. Du Bois. Unlike most commentators, Du Bois had actually been a public-school teacher in rural Tennessee; he long remembered the lack of basic classroom resources and the many material struggles of country life. ${ }^{66} \mathrm{He}$ saw media spectacles as distractions from more pressing economic and racial issues, and he stressed that "the folk who leave white Tennessee in blank and ridiculous ignorance ... are the same ones who would leave black Tennessee and black America with just as little education as is consistent with fairly efficient labor and reasonable contentment." ${ }^{67}$ Still, the trial had divided national opinion and dominated the news for weeks, so Du Bois did not simply dismiss it as insignificant. He also thought that culture mattered politically, especially as testimony, and he contested attempts to depoliticize cultural claims. Ultimately Du Bois argued that real democracy required honest and critical public debates, to which he saw Scopes-style conflicts as serious political obstacles. ${ }^{68}$ So, precisely because of its circus dynamics, the trial had exposed some difficult truths about the United States. "Dayton, Tennessee, is America," Du Bois wrote: "a great, ignorant, simple-minded land, curiously compounded of brutality, bigotry, religious faith and demagoguery, and capable not simply of mistakes but of persecution, lynching, murder and idiotic blundering, as well as charity, missions, love and hope."69

But these claims remained catnip for Mencken. In Notes on Democracy (1926), Mencken continued to mobilize conflicts between the urban "civilized minority" and the rural "eternal mob." A musician playing Bach in Tennessee, for example, "would be hailed before a Judge Raulston, tried by a jury of morons, and railroaded to the calaboose." 70 This kind of combative iconoclasm helped consolidate Mencken's celebrity as perhaps the most influential critic in the United States. In 1926 he was the subject of over five hundred editorials; he loomed above cities on billboards; he compiled any publicity about himself for further distribution by his publishers. $^{71}$ Notes on

${ }^{66}$ David Levering Lewis, W. E. B. Du Bois, I889-19I9: Biography of a Race (New York: Henry Holt, 1993), 67-72. Du Bois worked in Tennessee's black public schools on summer vacations from Fisk University in the i 880 .

${ }^{67}$ W. E. B. Du Bois, "Scopes," The Crisis, Sept. 1925, 2 1 8.

${ }^{68}$ W. E. B. Du Bois, "Criteria of Negro Art," The Crisis, Oct. 1926, 290-97; Eric King Watts, "Cultivating a Black Public Voice: W. E. B. Du Bois and the "Criteria of Negro Art'," Rhetoric and Public Affairs, 4, 2 (Summer 200I), I $8 \mathrm{I}-20 \mathrm{I}$; Stephanie J. Shaw, W. E. B. $D u$ Bois and The Souls of Black Folk (Chapel Hill: University of North Carolina Press, 2013), 15-36; Nick Bromell, "'Honest and Earnest Criticism' as the 'Soul of Democracy': Du Bois's Style of Democratic Reasoning," in Bromell, ed., A Political Companion to W. E. B. Du Bois (Lexington: University Press of Kentucky, 20 I 8), 159-80.

${ }^{69}$ Du Bois, "Scopes," 2 I 8.

$7^{70}$ H. L. Mencken, Notes on Democracy (New York: Alfred A. Knopf, 1926), 64.

${ }^{71}$ Rodgers, Mencken, 3 I I. 
Democracy appealed to Joseph Wood Krutch as a "Rabelaisian disquisition," while Lippmann argued that Mencken's book revealed "the paradox of his popularity." ${ }^{2}$ This paradox was that Mencken's whole mode of cultural criticism did not simply oppose spectacular conflicts like the Scopes trial, but also crucially depended on their continuation. "I enjoy democracy immensely," Mencken had concluded. "It is incomparably idiotic, and hence incomparably amusing." ${ }^{3}$ But if conflicts between Mencken's audience and Bryan's constituency became dominant politically, and if this continued to drive editorial and economic decisions across the newspaper industry, then perhaps the circus would continue indefinitely. Mencken's audience expected spectacular excess from Bryan's constituency for its fun; Bryan's constituency demanded a certain disdain from Mencken's audience for its force. If each depended on the other's opposition, and if the media went on profiting from their symbiosis, then the political consequences would be circular and conservative.

Among the many liberals made anxious by this mode of politics, few fretted more than white southern advocates of the New South. For this project was now old, while the South still seemed vulnerable to Mencken. The sociologist Howard Odum argued for more modernization and social science, but he also began to see this frankly as "a peace without victory ... Better a decade of research than a cycle of futility," he concluded forlornly. ${ }^{74}$ The literary critic Edwin Mims tried to trumpet progress in The Advancing South (1926); he conceded that "Mencken's violent diatribes have strengthened the conservative forces," but concluded that southern public opinion had nonetheless witnessed a "rising tide of liberalism."7s Mims argued that white elites should manage regional modernization, maintain racial segregation, and minimize Scopes-like debacles. But Mencken responded by blaming the trial on "Mims and his fellow pussyfooters" for lacking the will to lead the South. ${ }^{76}$ Both Mims and Odum, moreover, were part of the broader problem that $\mathrm{Du}$ Bois had identified, because their basic positions were elitist, racist, and wishful. Even their friends found them implausible. When the novelist Ellen Glasgow read The Advancing South she doubted that such priggish stuff could achieve much, and she told Mims that "fanaticism, intolerance

72 Joseph Wood Krutch, “Mr. Mencken's Best,” Nation, I Dec. 1926, 603; Walter Lippmann, "H. L. Mencken," Saturday Review of Literature, i I Dec. 1926, 413-14.

${ }^{73}$ Mencken, Notes on Democracy, 2 I I.

${ }^{74}$ Howard W. Odum, "The Duel to the Death," Social Forces, 4, I (Sep. 1925), I 89-94, I94; Michael O'Brien, The Idea of the American South, 1920-1940 (Baltimore: Johns Hopkins University Press, 1979), 42-43.

${ }^{75}$ Mims, The Advancing South, vii, 16-17, 302-3; Michael O'Brien, Rethinking the South: Essays in Intellectual History (Baltimore: Johns Hopkins University Press, I 988), I 3 I-56.

${ }^{76}$ H. L. Mencken, "The South Looks Ahead," American Mercury, Aug. 1926, 506-8; Ring, The Problem South, 216-20. 
and hypocrisy" were "beginning to boil over again" across the whole country. ${ }^{77}$

Menckenian conflicts and spectacles continued to shape the American mainstream in the later I920s. Sinclair Lewis seized the moment with Elmer Gantry, a ruthless satire on small-town fundamentalism dedicated to Mencken that became America's best-selling novel in 1927. To research it Lewis had travelled to Kansas City, Missouri, where he befriended many liberal ministers. But in the novel itself the preacher protagonist is venal and lascivious, while the earnest antagonist ends up a mob victim after speaking out about "the 'monkey trial' at Dayton." ${ }^{8}$ Lewis's publishers told him that "the publicity on Elmer Gantry is amazing ... We are advertising it, of course, in every conceivable way from here [New York] to the Pacific Ocean."79 Thus Elmer Gantry extended and deepened the trial's earlier conflicts as entertaining and popular fiction. Krutch reviewed it diffidently as a book about the American grotesque, while Lippmann criticized Lewis directly for turning his characters into "stereotypes." 80 Still, so much publicity surrounded Elmer Gantry that even its critics seemed complicit in its consequences. "Mr. Lewis's types," wrote the labor journalist Benjamin Stolberg, "are but the moron victims crowding at the right wing of a culture at whose enlightened left wing Mr. Lippmann sits as a connoisseur and critical apologist." ${ }^{1}$

Here was the difference between how socialists and liberals understood the politics of cultural conflict. Stolberg agreed with Lippmann "when he says that there is an ever-widening cultural gap between the industrial centers and the country districts," but they disagreed about both why and what to do. ${ }^{82}$ Lippmann sought to bridge the gap and calm the circus with a broadly liberal consensus. Three months after the trial ended Lippmann addressed the annual meeting of the Indiana State Teachers' Association in a huge fundamentalist church, the Cadle Tabernacle of Indianapolis, where he argued that schools and newspapers could together produce better

77 Ellen Glasgow to Edwin Mims, I 2 May 1926, in Letters of Ellen Glasgow, ed. Blair Rouse (New York: Harcourt, Brace, 1958), 79-80.

${ }_{78}$ Sinclair Lewis, Elmer Gantry (New York: Harcourt, Brace, 1927), 390.

79 Alfred Harcourt to Sinclair Lewis, 3 I March 1927, in James M. Hutchisson, The Rise of Sinclair Lewis, 1920-1930 (University Park: Penn State University Press, 1996), 1 59-60. See also John Tyler Blake, "Sinclair Lewis's Kansas City Laboratory: The Genesis of Elmer Gantry," PhD thesis, University of Missouri-Kansas City, 1998, 252-99; Andrew Seal, "The Common Man: An Intellectual History of the New Middle Class, I880I 950," PhD thesis, Yale University, 2017, 330-44.

80 Joseph Wood Krutch, "Mr. Babbitt's Spiritual Guide," The Nation, I6 March 1927, 29192; Walter Lippmann, Men of Destiny (New York: Macmillan, I927), 71-92, esp. 88-91.

${ }^{81}$ Benjamin Stolberg, "Walter Lippmann: Connoisseur of Public Life," The Nation, 7 Dec. 1927, 639-42.

82 Ibid. 
public debates. ${ }^{83}$ However, Stolberg saw cultural conflicts as political distractions from wider economic struggles; he wanted to stop the circus by changing the subject. Stolberg spent most of his time covering strikes and other union issues at a low moment for the labor movement, though he also helped Lewis research a never-finished "labor novel." ${ }^{84}$ Lippmann kept writing about Scopes and even tried Socratic dialogues in American Inquisitors (1928), where Bryan and Jefferson and others discuss various schemes of public education. Yet the dialogues reach few conclusions and when "Mr. Mencken" crops up the suspiciously Lippmann-like Socrates gets flustered and confused. ${ }^{85}$

The trap of the trial, then, lay in how its circus politics framed the spectacle of cultural conflict as the overwhelming and inescapable fact of American life. To many contemporary observers, these were the dynamics that shaped the 1928 election, when the Republicans and Democrats offered familiar economic orthodoxies and clear cultural contrasts in the presidential candidacies of Herbert Hoover and Al Smith. ${ }^{86}$ As Bryan's old Democratic rival and as the governor of New York, Smith struggled to win over white southern voters who resented what George Fort Milton called "his dripping wet views, his Tammany origin, background and environment, and his general Manhattanite point of view." ${ }^{87}$ In the end Smith lost not only Tennessee but also New York, while Norman Thomas carried the small socialist rump, and Hoover won a crushing victory for conservative normalcy. Trying to make sense of this result, Nation editor Oswald Garrison Villard argued that the anti-Catholic "whispering campaign" against Smith suggested that the "dense ignorance and prejudice of the Scopes case in Tennessee, which we had flattered ourselves was limited to backwoods districts, are in reality to

${ }^{8}$ Walter Lippmann, "The Common Responsibility of the School and the Press to the Public Welfare," speech to Indiana State Teachers' Association, 23 Oct. 1925, Robert O. Anthony Collection of Walter Lippmann, Yale University Library, Box 5 I, Folder 5.

${ }^{84}$ Hutchisson, 195-204; Christopher Phelps, "Heywood Broun, Benjamin Stolberg, and the Politics of American Labor Journalism in the r 920 and 1930s," Labor: Studies in WorkingClass History, i 5, I (March 2018), 25-5 I.

${ }^{85}$ Walter Lippmann, American Inquisitors: A Commentary on Dayton and Chicago (New York: Macmillan, 1928), 99-101, 106-7.

${ }^{86}$ Scholars have often debated the extent to which the 1928 election laid foundations for the New Deal coalition: e.g. Allan J. Lichtman, Prejudice and the Old Politics: The Presidential Election of 1928 (Chapel Hill: University of North Carolina Press, I 979); McGirr, The War on Alcohol, I 57-88. Here what matters is not the nature of partisan realignment, but the more limited claim that Scopes-style conflicts shaped public debates about the election; this claim is compatible with recent suggestions that Smith's economic agenda was more progressive than has been appreciated, for which see Robert Chiles, The Revolution of '28: Al Smith, American Progressivism, and the Coming of the New Deal (Ithaca, NY: Cornell University Press 2018).

${ }^{87}$ Robert A. Slayton, Empire Statesman: The Rise and Redemption of Al Smith (New York: Simon and Schuster, 200I), 240. 
be found in every American community." 88 More starkly, Du Bois argued that the election both exposed and betrayed democracy itself. Urgent issues like "the role of organized wealth in industry, the future of organized labor, the distribution of national income," Du Bois wrote, had been evaded again by a campaign that seemed to deepen public apathy and systematically ignore the ongoing disenfranchisement of African Americans. Du Bois's doubts about democracy in America grew with both his dejection at the election and his scorn for Scopes-style circuses. ${ }^{89}$

Many white liberals, meanwhile, continued to argue that the trial's trap could only be escaped by doubling down on consensus through modernization. Where this argument had once been made by the New South partisans like Odum and Mims, now it was developed by more national figures like Lippmann and Krutch. For example, Krutch's disenchanted study of The Modern Temper (1929) identified stoicism and humanism as sources of hope for a liberal modernity, and yet concluded austerely that "unresolvable discord" would remain "the fundamental fact" of "the world in which we must continue to live." 90 Similarly, but a bit less bleakly, Lippmann's Preface to Morals (1929) argued that "the acids of modernity" corroded old certainties but also created a "complex pluralism" that could sustain more moderate and tolerant forms of democratic politics. ${ }^{91}$ On this view, the very process of modernization would create consensus eventually. Liberals might push it along through middlebrow public moralism; Lippmann's Preface to Morals became a best seller and a Book-of-the-Month Club selection. ${ }^{22}$ They could also study modernization's sociology, especially the apparent "lag" between economic change and cultural habits, through Robert S. and

${ }^{88}$ Quoted in Charles E. Delgadillo, “'A Pretty Weedy Flower': William Allen White, Midwestern Liberalism, and the I920s Culture War," Kansas History, 35, 2 (Autumn 2012), I 86-202, 199 .

89 W. E. B. Du Bois, "The Possibility of Democracy in America," The Crisis, Sept-Oct. 1928, 295-96, 314-1 5, 336, 353-55. On his later thought see Eric Porter, The Problem of the Future World: W. E. B. Du Bois and the Race Concept at Midcentury (Durham, NC: Duke University Press, 2010).

90 Joseph Wood Krutch, The Modern Temper: A Study and a Confession (London: Jonathan Cape, I930; first published 1929), 247. On his politics see Ramona June Grey, "Modern Liberalism and Despair: The Pilgrimage of Joseph Wood Krutch," American Studies, 38 , I (Spring 1997), 81-96, esp. 91.

${ }^{11}$ Walter Lippmann, A Preface to Morals (New York: Macmillan, 1929), 19, 270-79, 31 6-19.

$9^{2}$ On the emergence of a middlebrow cultural register during this period see Joan Shelly Rubin, The Making of Middlebrow Culture (Chapel Hill: University of North Carolina Press, 1992); Janice A. Radway, A Feeling for Books: The Book-of-the-Month Club, Literary Taste, and Middle-Class Desire (Chapel Hill: University of North Carolina Press, 1997); Matthew S. Hedstrom, The Rise of Liberal Religion: Book Culture and American Spirituality in the Twentieth Century (New York: Oxford University Press, 2013). 
Helen Merrell Lynd's Middletown (1929). 93 The post-Scopes liberal hope, then, was that consensus would emerge through the gradual but inexorable consolidation of a middlebrow Middletown modernity. ${ }^{94}$

Conservatives responded to this position by developing explicitly antimodern and antiliberal modes of cultural politics. Thus the Southern Agrarians, a group of writers and critics variously associated with Vanderbilt University, argued that southern culture was a crucial conservative exception to an otherwise liberal modernity in I'll Take My Stand (1930). John Crowe Ransom, the leading Agrarian, claimed that the South's cultural heritage was old and European; that its contemporary identity was rural, religious, and white; and that its political hopes still lay with the Bryanite wing of the Democratic Party.95 While northern liberals argued that modernization would destroy what remained of Bryan's constituency, southern conservatives tried to reclaim it as a political vehicle for antiliberal cultural campaigns. Ransom later retreated from these positions along with many other Agrarians, not least because other southerners accused them of evading the issue of segregation. ${ }^{6}$ Nevertheless, Donald Davidson came to see the Scopes trial as a national humiliation. He continued to dwell on its implications and argued in I'll Take My Stand that southern conservatives needed to promote an "agrarian restoration." 97 By the 1950s Davidson had embraced

93 Robert S. Lynd and Helen Merrell Lynd, Middletown: A Study in Contemporary American Culture (New York: Harcourt, Brace, i 929).

${ }^{4}$ E.g. Henry James Foreman, "What's Right with America?", McCall's Magazine, Nov. I929, I 8-19; here Lippmann, Lewis, Robert Lynd, and Will Durant argued that modernization would lead to the normalization of a national liberal consensus. For a mordant response from Middletown see Sarah E. Igo, The Averaged American: Surveys, Citizens, and the Making of a Mass Public (Cambridge, MA: Harvard University Press, 2007), 49; here the local journalist E. C. White pressed Lynd for further details about "normal living. Shall the tooth brushes be thrown away," she asked, "or the ancient hymns discarded? Let the oracle speak!"

95 John Crowe Ransom, "Reconstructed but Unregenerate," in Twelve Southerners, I'll Take My Stand: The South and the Agrarian Tradition (Baton Rouge: Louisiana State University Press, 1983; first published 1930), I-27. On his intellectual biography see O'Brien, Idea of the American South, I I-26; Murphy, The Rebuke of History, 54-56.

${ }^{96}$ E.g. Clarence Cason, $90^{\circ}$ in the Shade (Chapel Hill: University of North Carolina Press, 1935), 48, 62; W. J. Cash, The Mind of the South (New York: Vintage, I94I), 389-94.

97 Donald Davidson, "A Mirror for Artists," in Twelve Southerners, 28-60, 30. For his continuing interest in the Scopes trial see Donald Davidson, "First Fruits of Dayton: The Intellectual Evolution in Dixie," in Emily S. Bingham and Thomas A. Underwood, eds., The Southern Agrarians and the New Deal: Essays after I'll Take My Stand (Charlottesville: University of Virginia Press, 200I), 35-49; O'Brien, The Idea of the American South, I87; Maxwell, The Indicted South, 90-91, I I 8-24, I63-64. Cf. Murphy, which at 147 cautions against seeing the trial as "instigating Agrarianism," and which shows throughout how Agrarians like Allen Tate and Robert Penn Warren differed from Ransom and Davidson. 
white supremacist activism as chair of the Tennessee Federation for Constitutional Government (a massive-resistance organization) and he openly argued that defending southern culture meant advocating "democracy for white people." ${ }^{8}$ Davidson's career thus realized some of the most revanchist dimensions of conservative cultural politics.

On the far right in the 1930s, moreover, this kind of politics was radicalized still further. In Kansas, for example, the fundamentalist preacher and fervent anti-Semite Gerald B. Winrod regularly invoked Scopes-style conflicts to claim that cultural threats like evolution and Elmer Gantry were destroying "true American civilization." 999 This looked a lot like fascism to many contemporaries. ${ }^{100}$ In Sinclair Lewis's It Can't Happen Here (1935) the dictator Buzz Windrip was partly inspired by Winrod, while the hero Doremus Jessup says directly that fascism could well happen in a country where Bryan had "made the whole world laugh itself sick by forbidding the teaching of evolution." "о But as Stolberg also observed, American fascism often reflected contingent alliances between capitalist elites and conservative activists that mobilized deeply modern forms of mass communication. "To play the fascist game," Stolberg argued, was to produce violently cynical versions of right-wing vigilantism that could play ambiguously on spectacular rumors of corruption and conspiracy. ${ }^{102}$ The American far right in the 1930 s partly relied on shrewd media strategies to radicalize such rumors into an imminent sense of civilizational collapse. ${ }^{103}$ And figures like Winrod built directly on

${ }^{8}$ Donald Davidson, Still Rebels, Still Yankees and Other Essays (Baton Rouge: Louisiana State University Press, 1957), 209. Cf. Jason Morgan Ward, Defending White Democracy: The Making of a Segregationist Movement and the Remaking of Racial Politics, 1936-1965 (Chapel Hill: University of North Carolina Press, 2014).

${ }^{9}$ Leo P. Ribuffo, The Old Christian Right: The Protestant Far Right from the Great Depression to the Cold War (Philadelphia: Temple University Press, I983), 8 I-I I 8, 92; Lienesch, In the Beginning, I 86, 199.

${ }^{100}$ In Kansas liberals and socialists ranging from William Allen White to Marcet HaldemanJulius formed a united front against Winrod, who still won a fifth of the vote in the 1938 Republican primary for the US Senate. For an explicit comparison of Winrod with Bryan see William Allen White to Franklin D. Roosevelt, Io June 1938, in Selected Letters of William Allen White, ed. Walter Johnson (New York: Henry Holt, I 947), 386-89.

${ }^{101}$ Sinclair Lewis, It Can't Happen Here (Garden City, NY: Doubleday, I 935), 2 I-22.

${ }^{102}$ See Joseph Fronczak, "The Fascist Game: Transnational Political Transmission and the Genesis of the U.S. Modern Right," Journal of American History, I05, 3 (2018), 563-88, esp. 585 (on Stolberg).

${ }^{103}$ Beyond Fronczak and Ribuffo see e.g. Alan Brinkley, Voices of Protest: Huey Long, Father Coughlin, and the Great Depression (New York: Alfred A. Knopf, 1982); June Melby Benowitz, Days of Discontent: American Women and Right-Wing Politics, 1933-1945 (DeKalb: Northern Illinois University Press, 2002); Christine K. Erickson, "II Have Not Had One Fact Disproven': Elizabeth Dilling's Crusade against Communism in the I930s," Journal of American Studies, 36, 3 (Dec. 2002), 473-89; Allan J. Lichtman, White Protestant Nation: The Rise of the American Conservative Movement (New York: 
earlier cultural conflicts to push conservative claims to their rightmost extremes. These claims thus show how starkly the Scopes circus could become, as Du Bois had warned, "no laughing matter." ${ }^{104}$ Far-right cultural crusades and even fascist games were ominous possibilities that lurked within the trial's conservative trap.

\section{III}

During and after the 1930s, debates about what the Scopes trial had meant changed while the American political mainstream moved away from earlier cultural conflicts. But the trial's trap continued to animate conservative arguments that could be variously escaped, negotiated, or intensified down the twentieth century. The New Deal moved away from the Scopes circus mostly through a basic political emphasis on confronting economic and international crises, but also through targeted cultural agendas that promoted a national liberal consensus. For example, the Federal Writers' Project produced a series of state guidebooks that provided a "road map for the cultural rediscovery of America." ${ }^{105}$ One Tennessee tour suggested briefly stopping in Dayton before swiftly proceeding to Chattanooga, where you could see the promise of the Tennessee Valley Authority. ${ }^{106}$ With such state-led modernization projects providing jobs alongside a popular cultural nationalism, the New Deal tried to drive Americans away from the 1920s and toward more forwardlooking modes of modern liberalism. George Fort Milton saw the TVA as the South's salvation, while Donald Davidson opposed it as a Yankee

Atlantic, 2008), 59-104; Matthew Avery Sutton, "Was FDR the Antichrist? The Birth of Fundamentalist Antiliberalism in a Global Age," Journal of American History, 98, 4 (March 2012), 1052-74.

${ }^{104}$ Du Bois, "Scopes," 2 1 8. Another far-right movement that partly built on the trial's cultural conflicts was the Ku Klux Klan; Du Bois linked them explicitly together in "The Shape of Fear," North American Review, June-Aug. 1926, 291-304, 296. On the Klan as a cultural crusade see Felix Harcourt, Ku Klux Kulture: America and the Klan in the Igros (Chicago: The University of Chicago Press, 2017).

${ }^{105}$ Jerrold Hirsch, Portrait of America: A Cultural History of the Federal Writers' Project (Chapel Hill: University of North Carolina Press, 2003), 19. On the variety and direction of New Deal cultural politics see Jonathan Harris, Federal Art and National Culture: The Politics of Identity in New Deal America (Cambridge: Cambridge University Press, 1993); Michael Denning, The Cultural Front: The Laboring of American Culture in the Twentieth Century (London: Verso, 1996); Victoria Grieve, The Federal Art Project and the Creation of Middlebrow Culture (Urbana: University of Illinois Press, 2009); Sharon Ann Musher, Democratic Art: The New Deal's Influence on American Culture (Chicago: The University of Chicago Press, 2015).

${ }^{106}$ Federal Writers' Project, Tennessee: A Guide to the State (New York: Viking, 1939), 257, $359-65$. 
imposition. ${ }^{107}$ Whether seen as savior or bulldozer, the TVA became a vivid symbol of liberal modernity within and beyond Tennessee during the r $930 \mathrm{~S}$ and I940s. Where the spectacle of cultural conflict had once produced a conservative circus politics, many now saw federal agencies like the TVA as evidence of "democracy on the march."

As the New Deal gave way to the Cold War, the Scopes trial reemerged in American memory on different political terms. The key text driving this change was Inherit the Wind, both as a 1955 play and as a 1960 film, but there were books and articles too. In these accounts the trial came to matter mostly as a debate about science and religion and as a contest over individual rights, while its cultural conflicts were downplayed as basically harmless ballyhoo from a bygone era. ${ }^{109}$ Both the play and film versions of Inherit the Wind showed much frenetic media coverage, but as they proceed the circus recedes and the drama culminates with a struggle between scientific liberalism and religious reaction. The film ends with Spencer Tracey's Darrow humiliating Bryan (Fredric March) and distancing himself from Mencken (Gene Kelly); its final shot has Darrow leaving the courtroom with copies of both the Bible and Darwin as "The Battle Hymn of the Republic" plays in the background ("his truth is marching on!"). The trial's Cold War adaptations thus offered audiences straightforward morality tales that ended with clear victories for liberal modernity. As an anti-McCarthy production, Inberit the Wind took the position of Edward R. Murrow: demagogues were dangerous, the public was vulnerable, but a few good liberals could save the day. Still, many old features of the trial's trap endured. Conservatives in the 1950s continued to develop influential modes of media activism and antiliberal argument. ${ }^{110}$

${ }^{107}$ Edward S. Shapiro, "Donald Davidson and the Tennessee Valley Authority: The Response of a Southern Conservative," Tennessee Historical Quarterly, 33, 4 (Winter 1974), 436-5 I; James A. Hodges, "George Fort Milton and the New Deal," Tennessee Historical Quarterly, 36, 3 (Fall 1977), 383-409, esp. 404-6.

${ }^{108}$ David E. Lilienthal, TVA: Democracy on the March (New York: Harper \& Brothers, 1944). On its symbolic significance see David Ekbladh, "Meeting the Challenge from Totalitarianism: The Tennessee Valley Authority as a Global Model for Liberal Development," International History Review, 32, I (2010), 47-67.

109 Allen's Only Yesterday was republished as a mass-market Penguin paperback in 1938. The best mid-century account of the trial was Ray Ginger, Six Days or Forever? Tennessee v. John Thomas Scopes (Boston: Beacon Press, 1958), esp. 2 I 8-4 I (on science/religion and on individual rights). On Inherit the Wind and the Cold War see Albert Wertheim, "The McCarthy Era and the American Theatre," Theatre Journal, 34, 2 (May 1982), 2 I I-22; Larson, Summer for the Gods, 239-46; Randy Moore, "Creationism in the United States: The Lingering Impact of Inherit the Wind," American Biology Teacher, 6I, 4 (April 1999), 246-50.

${ }^{1}$ E.g. Glen Gendzel, "Pride, Wrath, Glee, and Fear: Emotional Responses to Senator Joseph McCarthy in the Catholic Press," American Catholic Studies, I 20, 2 (Summer 2009), 27-52; Michelle M. Nickerson, Mothers of Conservatism: Women and the Postwar Right (Princeton, 
When leading mid-century liberals argued about history and politics, however, they continued making claims about the need for consensus through modernization. For example, Richard Hofstadter framed American history since the 1890 s as a complex political response to modernity's inevitable advance. His Age of Reform (1955) portrayed Bryan's I 920 career as both a doomed last stand against modern liberalism and a persistent political impulse that anticipated McCarthy's "cranky pseudo-conservatism." " I I But as the American conservative movement became more and more powerful, the liberals found themselves stuck, because modernization had seemingly not delivered a durable national consensus. By the i 960 s Hofstadter's arguments were increasingly pathological; he now saw fundamentalism as "a type of pseudo-political mentality" and figures like Barry Goldwater as "paranoid." Earlier liberals like Lippmann had worried much about "the acids of modernity," but Hofstadter's generation went further by seeing the right as an extreme yet pseudo-political "revolt against modernity." ${ }_{12}$ From this perspective, conservative activists could be simultaneously diagnosed psychologically and dismissed politically as antithetical to modern America.

When the "culture wars" broke out in the I980s and 1990s, their many media spectacles replayed some old dynamics of the Scopes circus, yet now the political initiative lay firmly with conservatism. For despite the military metaphors and existential atmosphere, the culture wars framed circular arguments that generally favored the right. Conservatives stressed the need to defend traditional American values from liberal institutions, liberals decried the absence of consensus and the madness of conservatives, socialists found themselves marginalized from mainstream public debates, and the far right tried to turn these debates into revanchist political movements. ${ }^{113}$ Amidst

NJ: Princeton University Press, 2011); Nicole Hemmer, Messengers of the Right: Conservative Media and the Transformation of American Politics (Philadelphia: University of Pennsylvania Press, 2016).

${ }^{11}$ I Richard Hofstadter, The Age of Reform: From Bryan to F.D.R. (London: Jonathan Cape, 1962; first published 1955), 19, 286. On his earlier and more radical thought see Nick Witham, "Popular History, Postwar Liberalism, and the Role of the Public Intellectual in Richard Hofstadter's The American Political Tradition (1948)," Historical Journal, 59, 4 (Dec. 2016), I133-55. On the trial specifically see the recollections of Alfred Kazin, $A$ Lifetime Burning in Every Moment (New York: HarperCollins, 1996), 13-14: "When Dick [Hofstadter] read aloud from Mencken's unforgettable portrait of William Jennings Bryan at the Scopes trial ... I would sit back in an ecstasy of enjoyment that someone else equally relished every little bit of the American scene."

${ }^{112}$ Richard Hofstadter, Anti-intellectualism in American Life (New York: Alfred A. Knopf, 1963), I I 5-4I, I 34; Hofstadter, The Paranoid Style in American Politics and Other Essays (New York: Alfred A. Knopf, 1964). Cf. Harding, "Representing Fundamentalism," 391-93.

${ }^{113}$ Douglas Kellner, Media Spectacle (New York: Routledge, 2003); Andrew Hartman, $A$ War for the Soul of America: A History of the Culture Wars, 2nd edn (Chicago: The University of 
all this, various evolution trials were staged as "Scopes II," and one such case was Seagreaves v. California (1981). "Lacking a courtroom showdown," observed Leo Ribuffo, "ABC-TV's Nightline arranged a verbal shootout between science and religion, personified respectively by the astronomer Carl Sagan and the Far Right evangelist James Robison." Here oppositions between science and religion quickly became proxies for broader cultural conflicts when Sagan called the Bible "authoritarian" while Robison compared science books with comic books. ${ }^{14} 4$ Sagan died at sixty-two in 1996 as a celebrated science educator and anxious political liberal who sometimes called himself a socialist. ${ }^{15}$ Robison is now seventy-seven and he remains a leading voice of right-wing grievance. He became a spiritual adviser to Donald Trump in 2016 and promoted conspiracy theories about electoral fraud in 2020.116 After the assault on the US Capitol in January 202 I, Robison continued arguing that "liberal, secular, progressive socialists" both despised and mocked "the American 'deplorables,' 'scoundrels,' 'chumps' or 'mob,' or whatever hate-filled people wanted to label them." ${ }^{17}$

The political history of the Scopes trial has often been seen as a struggle between scientific progress and religious reaction, or as a contest over the rights and liberties of individuals like John Scopes. As this article has shown, however, the trial also framed a debate about the relationship between cultural conflict and media spectacle in the United States. Here the trial's circus dynamics became a kind of trap that induced much complacency within liberalism while also limiting the left. In the trial's aftermath liberals made the case for consensus through modernization, conservatives fought back by defending older cultural values, the far right worked to radicalize these values, and socialists found it very difficult to make claims about economic and racial justice. The Scopes trial thus promoted and reproduced some fraught conservative patterns of American political history. These patterns continue to create problems for liberals and the left, but they have no

Chicago Press, 2019; first published 2015), esp. 285-303 ("The Culture Wars Are Dead: Long Live the Culture Wars!").

${ }^{114}$ Leo P. Ribuffo, "Monkey Trials, Past and Present," Dissent, Summer 198 I, 358-61. For other cases see Eugene C. Bjorklun, "Evolution and Creationism: The Real 'Scopes II' Case," Religion \& Public Education, I 5, 2 (Spring 1988), 191-99.

in Carl Sagan, The Demon-Haunted World: Science as a Candle in the Dark (New York: Penguin, 1995).

${ }^{16}$ David Brody and Scott Lamb, The Faith of Donald J. Trump: A Spiritual Biography (New York: HarperCollins, 2018), 3 12-14; James Robison, "Can We Trust the Election Results?”, I Dec. 2020, at https://stream.org/can-we-trust-the-election-results-its-not-justabout-trump-its-about-truth.

${ }^{117}$ James Robison, "Hate Must Not Prevail," I9 Feb. 202 I, at https://stream.org/hate-mustnot-prevail. 
easy solutions, because the trial amplified and escalated the conflicts it staged without ever actually resolving them. Cultural conflicts have long shaped American politics and they can be perceived and negotiated more or less well. But they are not a war that anyone can win. And when they become all-consuming spectacles, the political consequences range from hypocrisy and resentment to cynicism and condescension, with the ultimate result of drastically reducing the scope for democratic action.

\section{AUTHOR BIOGRAPHY}

Tom Arnold-Forster is a Research Fellow in History at Gonville and Caius College, Cambridge. For helpful critical readings of earlier drafts of this article, huge thanks to Mark Edwards, Merve Fejzula, Julia Guarneri, Andrew Hartman, Daniel Hummel, Anton Jäger, Paul Murphy, Andrew Seal, Emma Teitelman, and the anonymous reviewers. 